\title{
Oral Giant Cell Granuloma in a Patient with Glycogen Storage Disease
}

\author{
Fabrício Rezende do Amaral, Vinicius Magalhães Carvalho, Marina Guimarães Fraga, Tânia Mara \\ Pimenta Amaral, Carolina Cavaliéri Gomes and Ricardo Santiago Gomez
}

Department of Oral Surgery and Pathology, School of Dentistry, Universidade Federal de Minas Gerais, Brazil

\begin{abstract}
The glycogen storage disease (GSD) is a group of inherited disorders that involve deficiencies in the enzymes that metabolize glycogen. The purpose of the present paper is to report a rare case of GSD type 1b that presented both peripheral and central giant cell granuloma, and to discuss the possible explanation for this unusual finding. The use of corticosteroids in the management of central giant cell granuloma is also demonstrated.
\end{abstract}

Keywords: Glycogen storage disease, giant cell lesion, treatment.

\section{INTRODUCTION}

Specific enzymes breakdown molecules of glycogen into glucose, which is used as a source of energy by the organism. The glycogen storage disease (GSD) is a group of inherited disorders that involves deficiencies in such enzymes [1]. The GSD is a rare autosomal recessive disease, and it exists in a variety of forms in accordance to specific enzymes involved [2].

In the GSD type1b, the enzyme glucose-6-phosphatase (G6P) cannot be transported across the microsomal membrane in the liver, and the glycogen cannot be metabolized [3]. The glycogen accumulates in several organs, such as liver and kidneys $[4,5]$, and the disease leads to systemic and intraoral manifestations. The main systemic manifestations are hypoglycemia, hyperlipidemia, hyperuricemia, hepatomegaly, short stature, growth retardation, neutropenia, and neutrophilic dysfunction with recurrent infections $[6,7]$. Patients with GSD1b show poor prognosis and high mortality rate [8].

The oral manifestations of GSD1b include severe periodontitis, bleeding diathesis, oral ulcerations, and dental caries $[9,10]$. A rare case of peripheral giant cell lesion associated with this disease has been previously described [11]. The purpose of the present paper is to report a GSD1b patient who presented both peripheral and central giant cell granuloma, and discuss a possible explanation for this unusual finding. The use of corticosteroids in the management of this condition is also demonstrated.

\section{CASE REPORT}

A male patient with consanguineous parents was first diagnosed with GSD type $1 \mathrm{~b}$ when he was six months old. At age 24, the Hematology Center referred him to the Oral Diagnosis Service of the Federal University of Minas Gerais to treat a hyperplasic lesion in the oral mucosa.

*Address correspondence to this author at the Faculdade de Odontologia, Universidade Federal de Minas Gerais, Avenida Antônio Carlos 6627, CEP 31.270-901, Belo Horizonte, Minas Gerais, Brazil;

E-mail: rsgomez@ufmg.br
As a consequence of lipid disturbance, the patient had his gallbladder removed. He presented hepatomegaly, hypoglycemia, short stature, and many previous episodes of recurrent infections including hospitalizations due to the neutropenia. In his first appointment, he showed low neutrophil numbers $\left(1.05 \times 10^{9} / \mathrm{L}\right.$; normal range from 1.7 to $\left.8.0 \times 10^{9} / \mathrm{L}\right)$ and a high level of uric acid $(11 \mathrm{mg} / \mathrm{dl}$; normal range from 3.4 to $7.0 \mathrm{mg} / \mathrm{dl}$ ). He was being treated with Granulokine 30 (Roche, Switzerland) for about 10 years (subcutaneous injection/ $1 \mathrm{ml} /$ alternating days), which is a granulocyte colonystimulating factor (G-CSF) and with Allopurinol (GlaxosmithKline, Rio de Janeiro, Brazil) (100 mg / 2x day) for uric acid control. Besides these drugs, he was also taking a vitamin complex (Protovit Plus) (Bayer, Rio de Janeiro, Brazil).

Intraoral assessment showed high levels of plaque and calculus, severe periodontitis with edematous gingiva, absence of tooth \# 47, dental caries and a hyperplasic purplish lesion in the lingual aspect localized adjacent to the teeth 32 , 33 and 34 (Fig. 1A). There was also a purplish tumoral lesion in the posterior alveolar ridge between teeth \# 46 and 48 (Fig. 1B). The panoramic $\mathrm{x}$-ray image of this area (Fig. 2A and 2B) revealed a nonspecific ill-defined rarefaction, without evidence of sclerosis at the margins. Widening of the periodontal ligament space, lamina dura destruction, and narrowed roots were present in those teeth. The axial computed tomography (CT) image (Fig. 2C) demonstrated that such lesion was non-expansible and extended to the mandibular canal. In addition, the lingual cortical and the alveolar bone were destroyed as confirmed by the coronal CT.

The patient underwent comprehensive non-surgical periodontal therapy. Teeth 26, 28, 36, 37, 46 and 48 were removed due to advanced periodontal disease. Based on a provisional diagnosis of pyogenic granuloma or peripheral giant cell granuloma, the anterior hyperplasic lesion was entirely removed through excisional biopsy. Histological examination confirmed the diagnosis of peripheral giant cell granuloma (Fig. 3A and 3B). In the posterior intra-osseous lesion, a fine needle aspiration biopsy was performed, but it was not contributive. Thus, an incisional biopsy was done and the time teeth 46 and 48 were extracted. The histological 

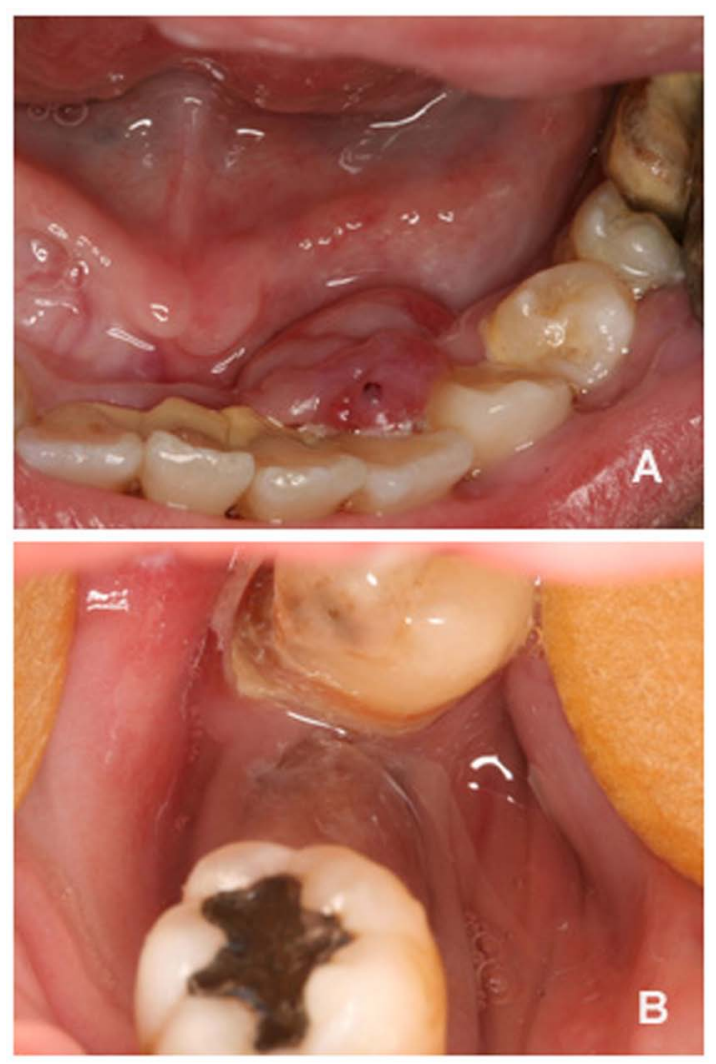

Fig. (1). Clinical aspects of the peripheral (A) and central giant cell lesion $(\mathbf{B})$.

diagnosis was central giant cell granuloma (Fig. 3C and 3D). The parathyroid hormone level was within the normal limits. After a discussion with the medical staff on how to approach the case, the intraosseous lesion was conservatively treated. A total volume of $0,5 \mathrm{ml}$ injections of corticosteroid (triam- cinolone, $20 \mathrm{mg} / \mathrm{ml}$ ) and local anaesthetic solution (lidocaine $2 \%, 1: 1)[12,13]$ were used. Intralesion applications were performed every fifteen days for three times. Two weeks after the third application, clinical and radiographic examinations suggested regression of the lesion and no further applications were necessary. There was no evidence of recurrence after 1 year of follow-up.

\section{DISCUSSION}

This case report emphasizes the importance of a multidisciplinary approach in the treatment of a patient with GSD type 1b. G-CSF and granulocyte-macrophage colonystimulating factor (GM-CSF) are usually used to increase granulocytes levels, and were described as being successful in reducing the number of recurrent infections associated with GSD type $1 \mathrm{~b}$ [14]. In the current report, the patient had been using G-CSF for 10 years, and presented central and peripheral giant cell granulomas.

Although speculative, we found a possible explanation between the use of G-CSF / GM-CSF and the development of giant cell granulomas. Both G-CSF and GM-CSF act in extracellular membrane receptors, such as c-fms. These receptors activate an important signaling pathway that differentiates progenitor myeloid cells into osteoclasts [15]. The multinucleated giant cells found in central and peripheral giant cell lesions present ultrastructural characteristics of osteoclasts [16]. Therefore, theoretically, the giant cell lesions reported in the present paper may have developed due to the constant stimulation of osteoclastogenesis induced by the G-CSF. It is important to note that the other case report of peripheral giant cell granuloma associated with GSD $1 \mathrm{~b}$ found in the literature was also in a patient who was using GCSF [11].

Despite this possible side-effect, such patients cannot interrupt the G-CFS usage due to the neutropenic state. The
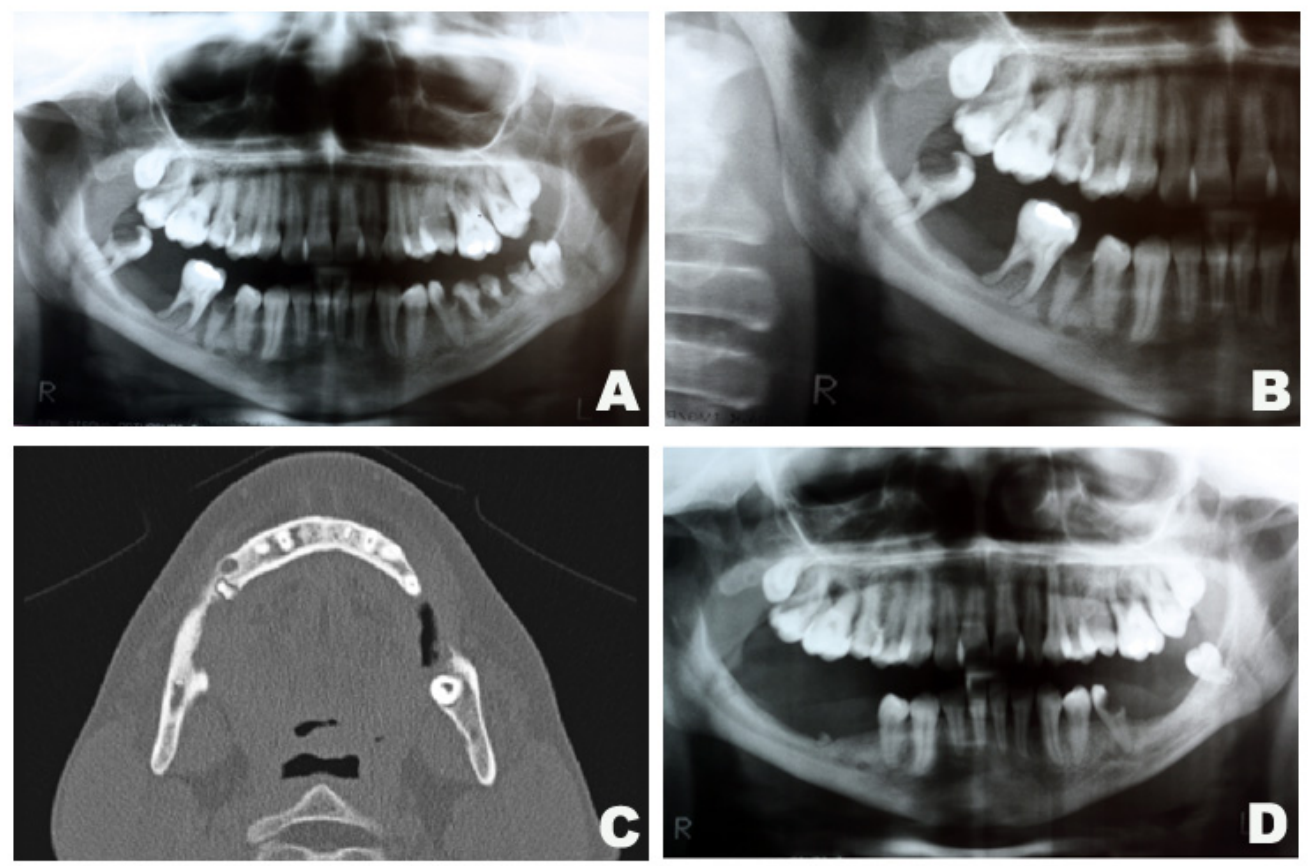

Fig. (2). Radiographic aspects of the central giant cell lesion. Panoramic x-ray depicting the lesion in the mandible (A and B). Axial CT showing bone destruction of the rigth side of the mandible measuring $13 \times 5 \mathrm{~mm}(\mathbf{C})$. Panoramic $\mathrm{x}$-ray after 1 year of follow-up (D). 

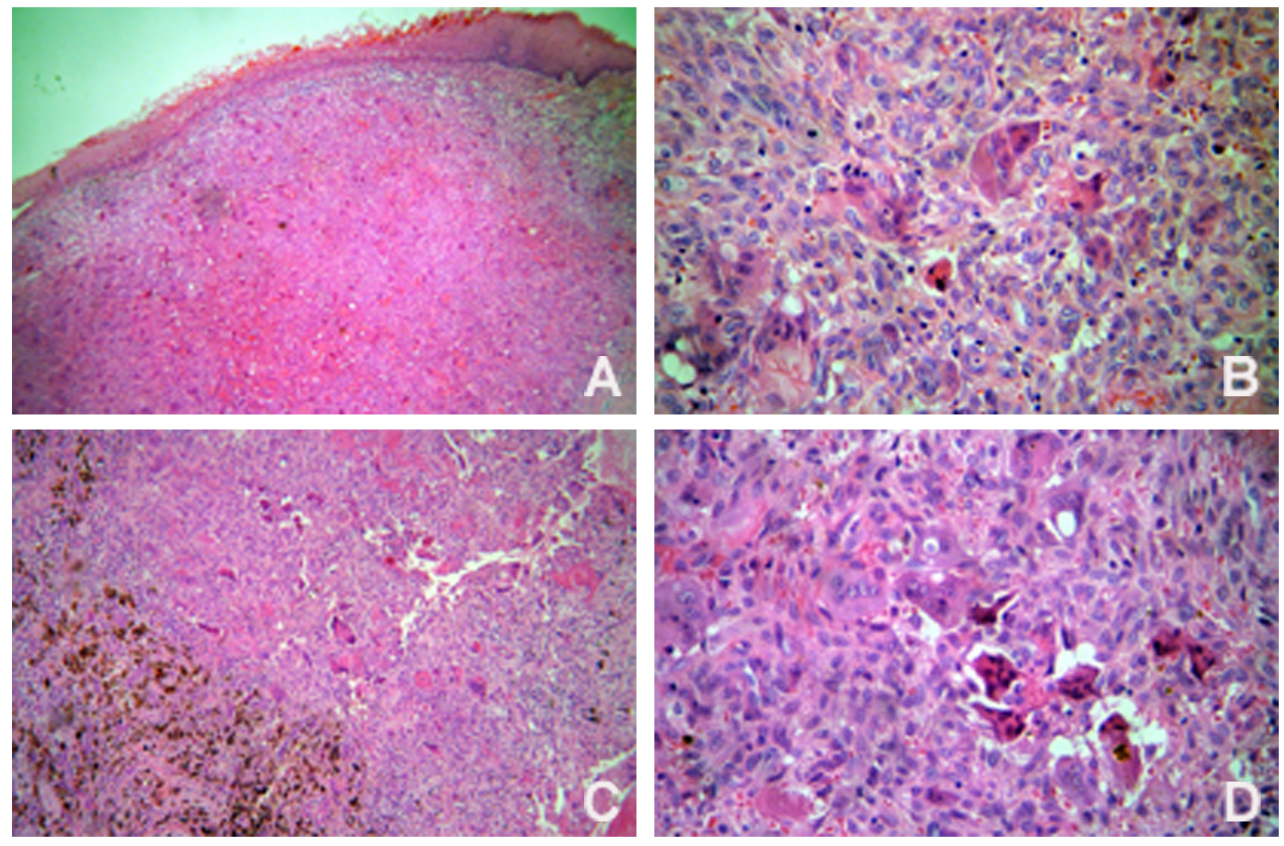

Fig. (3). Histopathological features of the peripheral (A and B) (Original magnification x 100 and x 400, respectively) and central giant cell lesions (C and D) (Original magnification x 100 and x 400, respectively).

patient of the current report is under follow-up for early diagnosis of possible additional lesions. It is important to mention that patients with GSD may be more susceptible to inflammatory periodontal disease. For that reason, such patients should be under strict maintenance protocols to control their periodontal health.

Corticosteroids usage has been previously reported in the management of central giant cell lesions $[12,13]$. This same approach in a patient with GSD was successfully described for the first time in this paper.

\section{ACKNOWLEDGEMENTS}

Dr. RS Gomez is research fellow of Conselho Nacional de Desenvolvimento Científico e Tecnológico (CNPq), Brazil.

\section{REFERENCES}

[1] Dougherty N, Gataletto MA. Oral sequelae of chronic neutrophil defects: case report of a child with glycogen storage disease type 1b. Pediatr Dent 1995; 17: 224-9.

[2] Martin AP, Bartels M, Schreiber S, Buehrdel P, Hauss J, Fangmann J. Successful staged kidney and liver transplantation for glycogen storage disease type Ib: A case report. Transplant Proc 2006; 38: $3615-9$.

[3] Pan CJ, Lin B, Chou JY. Transmembrane topology of human glucose 6-phosphate transporter. J Biol Chem 1999; 274: 13865-9.

[4] Katz J, Shenkman Z, Sela M, Rakotz M, Garty BZ. Oral manifestations and anesthesia considerations in a child with glycogen storage disease type 1b: case report. Pediatr Dent 1997; 19: 123-6.

[5] Braunwald E, Kurt J, Isselbacher KJ. Harrison's principles of internal medicine. $11^{\text {th }}$ ed. New York: McGraw-Hill 1987.
[6] Ozen H. Glycogen storage disease: New perspectives. World J Gastroenterol 2007; 13: 2541-53.

[7] Narisawa K, Ishizawa S, Okumura H, Tada K, Kuzuya T. Neutrophil metabolic dysfunction in genetically heterogeneous patients with glycogen storage disease type 1b.J Inherit Metab Dis 1986; 9: 297-300.

[8] Bianchi L. Glycogen storage disease I and hepatocellular tumors. Eur J Pediatr 1993; 152: S63-S70.

[9] Barret AP, Buckley DJ, Katelaris CH. Oral complications in type 1B glycogen storage disease. Oral Surg Oral Med Oral Pathol 1990; 69: 174-6.

[10] Salapata Y, Laskaris G, Drogari E, Harokopos E, Messaritakis J. Oral manifestations in glycogen storage disease type $1 \mathrm{~b}$. J Oral Pathol Med 1995; 24: 136-9.

[11] Mortellaro C, Garagiola U, Carbone V, Cerutti F, Marci V, Bonda PL. Unusual oral manifestations and evolution in glycogen storage disease type Ib. J Craniofac Surg 2005; 16: 45-52.

[12] Carlos R, Sedano HO. Intralesional corticosteroids as an alternative treatment for central giant cell granuloma. Oral Surg Oral Med Oral Radiol Endod 2002; 93: 161-6.

[13] Abdo EN, Alves LC, Rodrigues AS, Mesquita RA, Gomez RS. Treatment of a central giant cell granuloma with intralesional corticosteroid. Br J Oral Maxillofac Surg 2005; 43: 74-6.

[14] Visser G, Rake JP, Labrune P, et al. Granulocyte colonystimulating factor in glycogen storage disease type $1 \mathrm{~b}$. Results of the European study on glycogen storage disease type 1b. Eur J Pediatr 2002; 161: S83-S7.

[15] Kitaura H, Zhou P, Kim HJ, Novack DV, Ross FP, Teitelbaum SL. M- CSF mediates TNF-induced inflammatory osteolysis. J Clin Invest 2005; 115: 3418-27.

[16] Liu B, Yu SF, Li TJ. Multinucleated giant cells in various forms of giant cell containing lesions of the jaws express features of osteoclasts. J Oral Pathol Med 2003; 32: 367-75.

This is an open access article licensed under the terms of the Creative Commons Attribution Non-Commercial License (http://creativecommons.org/licenses/by-nc/3.0/) which permits unrestricted, non-commercial use, distribution and reproduction in any medium, provided the work is properly cited. 